\title{
Perceptions of students on the physical exams in clinical nursing practice
}

\author{
Percepções de estudantes sobre o exame físico na prática clínica do enfermeiro
}

Maria de Fátima Lima de Oliveira ${ }^{1}$, Waldemar Brandão Neto $^{2}$, Andrea Rosane Sousa Silva ${ }^{2}$, Ana Virginia Rodrigues Veríssimo $^{3}$, Ana Márcia Tenório de Souza Cavalcanti², Estela Maria Leite Meirelles Monteiro²

Objective: to understand the perceptions of students from an undergraduate course in nursing on the importance of physical exams in clinical nursing practice. Methods: a qualitative study with 12 students of a private institution. For data analysis, the method of interpretation of meanings was used, based on the hermeneutic-dialectic perspective. Results: directions have been identified which give the physical exam an objective dimension, in which the accuracy of propaedeutic techniques is essential, and a relational dimension in which to give meaning to human actions permeated by subjectivity, new forms of production clinical nursing care are used. Conclusion: the physical exam contributes to the development of critical thinking in nursing care for the safety of the patient and autonomy to act in the scope of the clinical practice.

Descriptors: Physical Examination; Nursing Process; Clinical Competence; Nurse-Patient Relations; Education, Nursing.

Objetivo: compreender as percepções de estudantes de um curso de graduação em enfermagem sobre a importância da realização do exame físico na prática clínica do enfermeiro. Métodos: estudo qualitativo com 12 estudantes de uma instituição de ensino superior privada. Para análise dos dados, utilizou-se o método de interpretação de sentidos, baseado na perspectiva hermenêutico-dialética. Resultados: foram identificados sentidos que atribuem ao exame físico uma dimensão objetiva, em que o rigor das técnicas propedêuticas é indispensável, e uma dimensão relacional, em que, ao dar significado às ações humanas permeadas por subjetividade, oportunizam-se novas formas de produção do cuidado clínico em enfermagem. Conclusão: o exame físico contribui para o desenvolvimento do raciocínio crítico na assistência de enfermagem, para a segurança do paciente e autonomia para atuação no âmbito da clínica.

Descritores: Exame Físico; Processos de Enfermagem; Competência Clínica; Relações Enfermeiro-Paciente; Educação em Enfermagem.

\footnotetext{
${ }^{1}$ Faculdade Integrada de Pernambuco. Recife, PE, Brazil.

${ }^{2}$ Universidade Federal de Pernambuco. Recife, PE, Brazil.

${ }^{3}$ Universidade de Pernambuco. Recife, PE, Brazil.
} 


\section{Introduction}

Nursing is a profession that, over time, has been constructing and improving its history ${ }^{(1)}$. Its evolution as health occupation was influenced by social, economic, political and cultural events that occurred in Brazil ${ }^{(1)}$, which allowed the expansion of education, skills of training and the construction of a specific body of knowledge. However, it is also necessary to convince society of its usefulness as a profession of health directed to the health needs of the people and community ${ }^{(2)}$. In order to overcome this challenge and strengthen its professional identity, nursing has sought to sensitize the scientific and professional community area as to the use, in the scenario of clinical practice, of instruments or technological models that qualify their work process and provide visibility to its action within the multidisciplinary health team.

To meet the health demands in contemporary times, in which the scientific paradigm has strongly influenced the practices and decisions in health care and nursing, the nursing process is gaining its due importance in the health care environment, becoming a concern for pedagogical and service managers, universities and health professionals. In Brazil, the realization of the nursing process was encouraged by Wanda de Aguiar Horta, in the 1970s, adopting, as a theoretical framework, the theory of basic human needs ${ }^{(3)}$.

The nursing process indicates a specific professional work and involves a set of dynamic actions and decisions of health aiming at the organization and planning of nursing care facing the bio-psychosocialcultural and spiritual needs of subjects, families and community. It also indicates the adoption of a particular method or way of doing (Systematization of Nursing Care), based on a system of values and moral beliefs and in the technical-scientific knowledge of the area $^{(4)}$. According to Resolution 358/2009(5) of the Federal Nursing Council, the nursing process must be implemented in any institution and health services, public or private, that requires professional nursing care, and its development is divided into five interrelated steps: I- Nursing Data Collection (or Nursing History), II- Nursing Diagnosis, III- Nursing Planning IV- Implementation, V- Nursing Assessment.

Steps I and II were considered as the most important in the application of the process as it is from them that all directions and behavior in the establishment of the nursing care plan are triggered. Thus, in order to elaborate the history of nursing and subsequently carry out the clinical analysis (nursing diagnosis) requires specific skills of the nurses with the domain of methods, techniques and language appropriate for the taking of decisions in clinical practice. It is at this point that the relevance of anamnesis (interview) and of the physical exam, elements that help the professional observation, communication, survey of subjective and objective data and the register of information that is necessary for the planning of care.

The physical exam should be performed in a systematic way, in cephalocaudal sense, guided by a thorough evaluation of all segments of the body, using the propaedeutic techniques: inspection, auscultation, percussion and palpation ${ }^{(2)}$. In addition, to value, at the time of the exam, the subjective, emotional, relational, attitudinal components, beyond the technicalscientific area, provides the nurse the opportunity of a holistic look to perceive the dimensions of the healthdisease-care process, what other professionals would not recognize. This helps to establish a specific field of nursing performance at the same time favors the patients with information that contribute to improve their health condition.

The essence of the clinical method in the care of the patients is not rational, not logical, which allows perceiving beyond the altered organ or system. In addition, it makes possible to overtake the boundaries of positivist science that limits the health care in the scope of the diseases because it reconciles the rational side that appropriates scientific knowledge with other aspects of the human nature which are still little known or unknown. It is important to value it, 
because the mysteries which are part of being healthy and being sick are in $\mathrm{it}^{(6)}$.

From this perspective, the importance of including the study of the physical exam in the various care systems is highlighted in which the nursing practice happens, whether in teaching, managing or assisting. The need to reformulate the pedagogical projects of university courses is already being discussed by the academic, scientific and professional community, from the initiatives of the Secretary of Education, such as the Programa Nacional de Reorientação da Formação Profissional em Saúde (Pró-Saúde) (Reorientation in Health Professional Education). Since overcoming strict care models to models focused on humanization and integral vision has represented a challenge. Facing that, the study proposes the following research question: How do students perceive the inclusion of physical exam within their academic experiences in nursing care and the contributions to clinical nursing practice? And the objective of understanding the perceptions of students from an undergraduate degree in nursing about the importance of physical exam in clinical nursing practice.

\section{Methods}

This is a qualitative study with students from the bachelor's degree in nursing from a private institution in the city of Recife, Pernambuco, Brazil.

12 nursing students participated in the research, selected by the help of teachers from the process disciplines of nursing care and semiotics. These, in turn, indicated key informants that had higher interest/affinity and satisfactory performance in activities related to the knowledge of the basic techniques of physical exam in the subjects. The criteria of inclusion were as follows: age over 18 years, be enrolled in a institution of education, have completed or be enrolled in the course of semiotics and regular participation in hospital practice field. And as criteria of exclusion: students from other institutions of educational who were studying isolated subjects, not having experienced a period of hospital practice. The number of students was not pre-determined, so that the setting of the number of interviews occurred through procedures of theoretical saturation, in which the researchers interrupted the phase of data collection for noticing repetition and the absence of new information ${ }^{(7)}$.

Data collection was conducted from October to November 2013 through semi-structured interview, whose script brought the data of characterization of the subjects and three guiding questions: What is your understanding of the physical exam? How can the physical exam contribute for the clinical practice of nurses? What suggestions would you give for changes/improvements in the teaching of physical exam in nursing? Individual interviews were made, in a previously reserved room in the institution of teaching and the time was scheduled with the students. Audio recording was used, with due authorization, and each interview lasted approximately 20 minutes, totaling about 240 hours. Subsequently, researchers conducted a full transcription of the statements and these were stored in databases for further analysis. To ensure confidentiality, the students were identified by the letter E followed by an Arabic number corresponding to the order of the interviews.

For data analysis, the method of interpretation of meanings was used, based on the hermeneutical dialectics which is aiming at interpreting the context, the motivations and the individual logics of the reports obtained $^{(8)}$. In the analytical and interpretative path, the following steps were taken: (a) comprehensive reading of the transcripts, aiming at the complete vision and seizure of the singularities of the material; (b) identification and thematic focus of the elements that emerged from the reports; (c) identification and questioning of explicit and implicit ideas in the empirical material; (d) search for wider socio-cultural meanings and implied in the statements of the research subjects; (e) elaboration of interpretative synthesis, trying to articulate the objective of the study and empirical data; and (f) dialogue between the explicit 
and implicit ideas and information provided by other studies on this theme.

The study complied with the formal requirements contained in the national and international standards of regulatory research involving human subjects.

\section{Results}

\section{Characterization of participants}

Among the students, nine were female and three male. As to the period of the course to which they belonged, four students were in the fourth, two in sixth and six in the eighth. Concerning the age, five participants were aged between 19 and 25 years, six between 29 and 38, one was 42 years old.

Among the students, ten mentioned having applied physical exam in patients during hospital practice, however, this issue was more thoroughly analyzed in the statements, when revealing certain difficulties, so that the physical exam could be incorporated in the nursing care during the experience of the nursing process in the theoretical and practical areas.

When asked which subjects would be considered relevant to the teaching of physical exam in nursing, students mentioned mainly: semiotics, anatomy, physiology. It is noteworthy that the lack of knowledge in the basic subjects can jeopardize the learning of the physical exam in its objective dimension and in the quality of the register made by the student. It is worth highlighting that subjects in the field of public health and family health were also mentioned, demonstrating the concern as to the use of physical exam in specific scenarios that require nursing care.

From the data analysis, nuclei of meanings emerged that can translate the meanings, facilities and difficulties of the physical exam, their contribution in the clinical nursing practice setting, as well as some recommendations.

\section{Perception of students on physical exam}

It is identified, from the statements of the students, that there is the inclusion of the physical examination as part of an overall evaluation of the patient, able to provide the nurse important information, not only in the biological aspect, but also in social, cultural, psychological, spiritual aspects which interfere in the health of the subjects. It is a complete assessment of the patient, assess the health, psychological status, assess the patient completly (E1). Understand all cephalocaudal aspects, normality and abnormality to help make a parameter of how the patient is in the physical and mental context (E2). It is the precursor of all, it all starts with the interview and physical exam, when we start to know the patient better in a way that we will not examine only the physical body, but mostly the psychological side (E5).

In the statements of the other students, meanings of the physical exam practice were identified as a technical procedure for the logical understanding of the functioning of the body and disease processes. The term "patient assessment as a whole," mentioned by the participants E3 and E4, shows that the students reproduce a "universal" concept rather disseminated by professionals and in some textbooks, but bearing a superficial concept without critical thinking. You can see the patient as a whole, skull-foot ... how he arrived (E3). Evaluation of the patients as a whole (E4). It's for you to put into practice some of what you learned, you identify the points. When we make physical exam, we see from abnormality (E12).

On the other hand, it is observed, that there is the recognition of physical exam as an expression of the communication, either verbal or nonverbal, as the act of touching the patient. It is a time to value emotions, feelings and expectations, facing the assistance in nursing: Physical examination is the contact, perception that nurses have about the problems that may arise, even if the patient does not speak (E7). 


\section{Facilities for physical exam}

The acceptance/participation and the desire of the patient to be examined were seen as facilities by one of the students, due to the establishment of a relationship of respect and empathy during the communication as well as the availability of specific material resources for the physical exam: The patient wanted to be examined, had availability of material such as thermometer, tensiometer, stethoscope had everything, so it was easy to do, auscultation was made (E8).

\section{Difficulties for the physical exam}

As difficulties, limitations in the phases of the physical exam were identified, pointing auscultation as the largest, and few opportunities to develop technical skill, generating insecurity. They also reported difficulties to approach the patient in order to establish the first contact as well as issues of time to have the physical exam. It was observed that the difficulties pointed out by the students, for the most part, come from the fragile understanding of the role of the physical exam and its applicability in the context of nursing care, seeing it as a exclusively technical procedure. The greatest difficulty is auscultation. We did not have a hearing sensitivity for auscultation with a stethoscope (E2). Difficulty is being insecure to do it (E3). You have time, first difficulty, and talk to the patient (E4). The nurse has very little time to perform physical exam and all its step by step (E7).

An important issue raised by participant E6 is regarding the participation of the nurse within the multidisciplinary team in health, in relation to clinical practice. The little knowledge of the work potential of the nurse, as well as the hegemony that medical knowledge has in the conduct of clinical practice, focusing on the performance of some and demarcating spaces of power, help the students, during their experience of practice, understand the activity of the physical exam as the sole responsibility of the health professional. The nurse does not have that space yet for physical exam. They are usually doctors who do it, when we come in and say "we are nursing students", patients think a little differently. There is a lack of an area for nursing within the hospital (E6).

\section{Contribution of the physical exam for the clinical practice of the nurse}

According to the students, the physical exam helps to provide autonomy for the nurse. When this health professionals know how to deal with medical conditions that require scientific knowledge and the development of critical thinking, they have the opportunity to contribute with a global vision of the health-disease-care system, unveiling dimensions that perhaps other professionals do not perceive.

Graduating students also pointed out that the application of the physical exam contributes for the nursing process, making the planning of care sensitive to the interventions of nurses and also causes changes in nurse-patient-family relationships, when appreciating moments of listening, exchanging and strengthening confidence. The statements show a concern for changes in nursing care models focused on mechanized and protocol actions that prevent the holistic professional act. It is the part of the autonomy of nurses in the area. Sometimes we go to practice and focus on doing routine things like checking blood pressure, checking heartbeat, respiratory rate, but the physical exam itself, we can see that it is not well made (E8). If the nurse did the clinic through physical exam, a lot would not go unnoticed, and would be an advantage for the patient (E11). Physical exam is the main starting point for the work of nurses (E3). It is to know the needs of the patient, and from that for see perspectives on how to act, what care plan to be traced, direct your conduct and nursing care (E9). It is to provide the nursing diagnosis, not only what he is feeling, but what's going on there around in the family, the environment in which he lives (E5). It is the patient-nurse contact, it helps to show trust to the patient. Promote speaking, the touch, the patient will be able to participate and be more at ease. Some patients are afraid to talk to the nurse or other professional what they're feeling (E6). You can notice the alterations, from their arrival until their discharge, you can observe the thickness of the skin, you can observe the appearance of wounds, pressure ulcers, how they are evolving and what the interventions of nursing for those situations would be (E7). 


\section{Recommendations for changes/improvements in the physical exam in undergraduate education}

Student expectations have been identified for improvement in the physical exam in undergraduate teaching institutions in nursing, which permeated restatements in relation to increased workload intended to theoretical content. As well as increased supply and better organization of classes which make possible to develop practical techniques and subjective skills necessary for the implementation of the physical exam, and the establishment of a close work between theory and practice, so that the student can identify possibilities of nursing practice with critical thinking, security and sensitivity. Very little workload and very extensive subject. We should practice more before going to the training in the laboratory we have in the institution ... We should develop our skills better (E5). We needed more practical classes. Have the students do and evaluate whether they really understood, if they really understood that. Besides, having professors with fewer students would help (E6). Higher correlation between theory and practice (E10).

It is also worth highlighting, that the statement of E12, which points out the concern with the provision of care to groups excluded from the society. Conduct training, consultations in institutions that had a lot of people, such as prisons, mental hospitals, that we had that contact with people (E12).

Other statements converged to changes in teaching methods, teacher training, higher offer of extension courses at the institution. It was mentioned by participant E9 the overvaluing of the use of anatomical models in practical teaching laboratory at the expense of classes in the practical field. The practice should be more thorough; professors should have more teaching practice with students. There was no sufficient laboratory, actually we just learned in the practice (E1). There could be learning workshops of physical exam, place students facing the situation, training with the other colleague. Organize extra courses within the nursing school to increase sensitivity (E2). Professional (instructor) trained and prepared to teach physical exam (E11). More practices in humans than with dolls, dolls do not have the same perception of the human being (E9).

\section{Discussion}

The report of the students, as to the experiences in the practice of physical exam demonstrated that they recognize the importance of this data collection technique for the Nursing Process, which supports its clinical practice. In the same way, the participants attribute to physical exam directions on objective dimensions, on the field of propaedeutic techniques, as to the subjective ones, related to communication, the psychological, social and cultural aspects of the patient. This understanding points to the importance of implementation of all the elements of the nursing process, in order to perform nursing care efficiently and sensitively. Furthermore, the incorporation of these actions will bring contributions for a more collaborative, safe clinical practice, committed with the humanization and well fair of the patient.

In this sense, it is understood that the physical exam is a complex activity that requires knowledge, practice, technique and expertise to support the taking of a clinical decision ${ }^{(9)}$. However, the nurse should consider that the time of the physical exam exceeds the limit of detection of pathologic conditions, it is an opportunity of a meeting between nurses and patient, favoring welcoming, the strengthening of emotional bonds and trust for identification of biopsycho-social-cultural-spiritual needs of the patient. In this context, the physical exam serves as the link between care and scientific knowledge of nursing ${ }^{(6,10)}$.

For some students, even having experienced the theoretical foundations of teaching of physical exam, the elaboration of a concept which is limited and without criticality is observed, in which places the physical exam as a specific phase of data collection, limited to screening for abnormalities and pathological situations, or even that, it allows to evaluate the patient as a "whole", but without thinking what this "whole" would be facing the complexity of taking care of people. This fact contributes to the fragmented view of the human being in which the biological aspects of 
the subjective and behavioral aspects are separated, resulting in protocol and mechanized practices.

The possibility of establishing interpersonal relationships and encouraging the participation of the patient in the care was pointed out by the students as a facilitating factor for the practice of the exam. Furthermore, the study of body language, emotions and touch, universes that integrate nursing care in its fullness, offers a non-verbal form of communication afforded by physical exam ${ }^{(11)}$. In moments of interaction between team members and patients, situations of nursing care can emerge in communication and involve: facial expressions, eye contact, touch, head movements, voice emission, approach and look ${ }^{(12)}$. Thus, it is feasible to think of strategies to raise awareness among students about the incorporation of these subjective indicators in the clinical evaluation of nursing.

As for the difficulties, the lack of appreciation and understanding of the work of the nurse was highlighted by the students, and the little space given to their participation in clinical practice. The relations of power that exist in dealing with health determine behaviors and attributions, which often do not respond to the demands of users and multiprofessional work with health. The need to rethink other ways to make the clinic, as well as the inclusion of informed technologies in the relationship and communication is also highlighted. The exercise of a clinic for all professionals who care about their worldviews is emphasized, but they should have a common focus to all, which is the care, and that is not specific domain of a professional category or field of knowledge ${ }^{(10)}$.

In the literature, a deficit in the quality of nursing records on the physical exam is evidenced by demonstrating that not all medical records of health institutions had physical exam registered by the nurses ${ }^{(13)}$. In many contexts, professionals tend to create a certain distance of these practices, not viewing as a tool that could provide excellent care, believing be the sole responsibility of the medical professional. A process of social deconstruction must take into account the historical and cultural roots of professional identity in the case of nursing, still, there is a great ignorance of the importance of the role of the nurse, as well as the notion that the exercise of the professional care does not require the acquisition of skills and abilities and technical and scientific knowledge. This reality exceeds society, it can spread among professionals and ultimately influence their practices.

The contributions to the clinical practice of nursing, was highlighted by students that the physical exam is not only able to bring autonomy and empower the nurses in the taking of decision, but also consolidates nursing as a scientific practice, which has specific knowledge able to positively impact the quality of health care indicators.

The practice of physical exam is not performed in an isolated was, nor it is an exclusive activity of some professionals, it is part of the first steps of the nursing process that integrates a methodology of assistance work, systematization of nursing care. The implementation of the Systematization of Nursing Care is provided for by law, and its significance is discussed in the management of quality and safety of the patient. However, in many of these services it turned into a mechanized way, used as a bureaucratic activity, without the worry of continuing education to act with critical and reflective awareness in caring.

The holistic training and privileged place that the nurses have in health care make them able to develop a kind of work that rescues and signals the importance of human values to other team professionals, as well as the exercise of a sensitive care, including in situations of pain, fear, suffering and pathological diagnosis that require so much concern of professionals. It is also believed that the greater involvement of the nurse in clinical practice, working in conjunction with the medical professional, enables reframing models of care in health, establishing dialogues with other matrices of knowledge, besides strengthening autonomy to the achievement of 
performance spaces that support the professional care.

When seizing the recommendations of students to a better use of the teaching of the physical exam, it is identified that the curriculum models are struggling to establish teaching-learning supported and fed by the practice. The students that experience the theoretical knowledge of the nursing work process, find themselves unable to experience real situations coming from the world of practice. This gap between what is taught in the course and what the professionals experiences in their practice is also confirmed by another study ${ }^{(14)}$, which points out that the university contributes to the fragmentation of knowledge, by providing the construction of dispersed knowledge in organized subjects, from the biomedical model. It also reveals that the lack of opportunities of experiencing caring and managing more during graduation, is translated into insecurity in professional practice, a fact verified by the students of this research.

In some situations, the student, when faced with the nurse service which was not prepared to understand the importance of physical exam as a scientific instrument of the process of work in nursing, generates low expectations about the possibilities to apply the theoretical knowledge learned in classroom. This situation contributes to a conflict in the student between pleasure to learn, to know, to participate in the activities proposed by the syllabus of the course and what actually is an activity inherent to the nurse in the practical field. In addition, there is another reality, the fact that many health services have poor conditions in service, with shortage of materials for basic procedures, structural problems, bureaucracy, insufficient dimensioning and demotivation of professionals, enables the resistance of the nurses as to the physical exam supporting clinical and caring activities $^{(15)}$.

The possibility of directing nursing care to groups in situations of vulnerability, such as psychiatric patients and people in the prison system, mentioned by students, reveals a concern to broaden the nursing consultation in specific scenarios, and as citizens of care, establish sensitive and favorable relationships to the promotion of health, with the ethical and humane commitment to essential health care.

Students clarified the need for more time for lectures and conducting practical activities in the laboratory before the activities of training in the field, so that they can prepare themselves for their first physical exam and have enough time to deal with the difficulties of a fragmented curriculum, to relate the physical exam with the other contents studied at the beginning of the course, which has also been pointed out by the literature $\mathrm{e}^{(16-17)}$.

Regarding the profile of the tutor/teacher of the practical classes, the importance of ongoing education activities in clinical nursing education has been demonstrated, besides the desire for the use of active methodologies in lab activities. The influence of the tutor in the performance of clinical practice has been demonstrated by researchers from Chile ${ }^{(18)}$. Currently, the use of clinical/realistic simulation, within the undergraduate education emerges as creative pedagogical resource to work feelings of fear and nervousness, improving the knowledge and allowing the nursing student to critically examine attitudes, abilities and clinical skills ${ }^{(19)}$.

Physical exam, as a technological instrument for the qualification of care requires a team work among nursing professionals and others who make up the health team, allowing the nurse to participate actively in assistance with decision-taking power, providing opportunity to dialogue, share information and build care actions, anchored on interdisciplinary issues which favors different knowledge in the search for solutions and adoption of good health practices. It is a change of paradigm in the way of working in health, in which models of care focused on mechanized and protocol actions are questioned, making room for models of humanistic care, permeated by subjective phenomena and complex looks to rescue the sense of caring in the human being. 


\section{Conclusion}

This study revealed that the perception of the students on the physical exam diverges in two dimensions: the semiotic techniques that seek signs of alterations and abnormalities of the body and the subjective ones that focus on interpersonal communication, emotions and motivations. These two dimensions intercommunicate and are crossed by the clinic because there is no way to examine without touching, interacting and communicating. To promote a good nursing diagnosis and to select interventions which are sensitive to their action is the ability to understand the dynamics of the production of health care.

It was observed that the difficulties mentioned by the students for the exercise of physical exam appear to be linked to the superficial concept of this practice, obstacles in the process of training, little involvement of the nurse in the use of this tool in the scope of the systematization of Nursing Care and the poor working conditions. On the other hand, the students revealed that if the nurses performed clinical practice conferred by physical exam, they would be contributing to the development of critical thinking in assistance to the safety of the patient and autonomy in their area in order to strengthen a specific area of theoretical and practical knowledge of nursing.

As recommendation for improvements in teaching physical exam, overcoming the gap between theory and practice, observed in many curricula, was identified, and still based on curative medicine and excessive techniques of the work in health. It is necessary to ensure a clinical nursing education to establish a dialogue with the reality of professional practice through strategies of teaching which cause problems and are anchored by the action-reflectionaction dialectics, which is able to contribute to the development of skills and abilities that lead to building a proactive, collaborative, sensitive, conscious, integrating professional profile that meets the demands of the complexity of care.
The small size of the sampling can be highlighted as a limitation of this study, which involved a particular group of nursing students. However, the qualitative design allowed to understand the experiences of the students as to the practice of the physical exam, in order to perceive them as learning challenges in promoting critical and reflective attitudes about the work process in nursing. It is suggested, finally, that these issues should be the focus of future research.

\section{Collaborations}

Oliveira MFL, Brandão-Neto W, Silva ARS contributed to the design of work, data collection, analysis and interpretation of the results. Veríssimo AVR, Cavalcanti AMTS and Monteiro EMLM contributed to the review of the article, writing, revision and final approval of the version to be published.

\section{References}

1. Carlos DJD, Padilha MI, Villarinho MV, Borenstein MS, Maia ARCR. Nursing schools in Northeastern Brazil (1943-1975). Rev Rene. 2014; 15(2):32633.

2. Bellaguarda MLR, Padilha MI, Pereira Neto AF, Pires D, Peres MAA. Reflexão sobre a legitimidade da autonomia da enfermagem no campo das profissões de saúde à luz das ideias de Eliot Freidson. Esc Anna Nery. 2013; 17(2):369-74.

3. Santos N, Veiga P, Andrade R. Importância da anamnese e do exame físico para o cuidado do enfermeiro. Rev Bras Enferm. 2011; 64(2):355-8.

4. Garcia TR, Nóbrega MML. Processo de enfermagem: da teoria à prática assistencial e de pesquisa. Esc Anna Nery. 2009; 13(1):816-8.

5. Conselho Federal de Enfermagem. Resolução no 358, de 15 de outubro de 2009. Sistematização da Assistência de Enfermagem e a implementação do Processo de Enfermagem em ambientes, públicos ou privados, em que ocorre o cuidado profissional de Enfermagem. [Internet]. 2009 [citado 2015 jul. 14]. Disponível em: http://www.cofen.gov.br/ resoluo-cofen-3582009_4384.html. 
6. Porto CC. Letters to students and physicians in Brazil. Rev Med Minas Gerais. 2015;25(3):438-40.

7. Fontanella BJB, Magdaleno-Júnior R. Saturação teórica em pesquisas qualitativas: contribuições psicanalíticas. Psicol Estud. 2012; 17(1):63-71.

8. Gomes R. Análise e interpretação de dados de pesquisa qualitativa. In: Minayo MCS, organizadora. Pesquisa social: teoria, método e criatividade. Petrópolis: Vozes; 2009. p. 79-108.

9. Silva CMC, Teixeira ER. Exame físico e sua integralização ao processo de enfermagem na perspectiva da complexidade. Esc Anna Nery. 2011; 15(4):723-9.

10. Vieira AN, Silveira LC, Franco TB. A formação clínica e a produção do cuidado em saúde e na enfermagem. Trab Educ Saúde. 2011; 9(1):9-24.

11. Silva CMC, Sabóia VM, Teixeira ER. O ensino do exame físico em suas dimensões técnicas e subjetivas. Texto Contexto Enferm. 2009; 18(3):458-65.

12. Rezende RC, Oliveira RMP, Araújo STC, Guimarães TCF, Santo FHE, Porto IS. Body language in health care: a contribution to nursing communication. Rev Bras Enferm. 2015; 68(3):490-6.

13. Costa SP, Paz AA, Souza EN. Avaliação dos registros de enfermagem quanto ao exame físico. Rev Gaúcha Enferm. 2010; 31(1):62-9.
14. Trevisan DD, Minzon DT, Testi CV, Ramos NA, Carmona EV, Silva EM. Education of nurses: detachment between undergraduation courses and professional practices. Ciênc Cuid Saúde. 2013; 12(2):331-7.

15. Azevedo DM, Azevedo IC, Holanda CSM, Santos QG, Vale LD, Cassiano AN. Da academia à realidade: uma reflexão acerca da prática do exame físico nos serviços de saúde. Saúde Transform Soc. 2013; 4(4):106-10.

16. Silva CMC, Valente GSC, Saboia VM, Teixeira ER. The physical examination and the nursing process: beyond dualism between theory and practice. Rev Enferm UFPE On line. [Internet]. 2014 [cited 2015 nov 20]; 8(supl 1):2281-6. Available from: http:// www.revista.ufpe.br/revistaenfermagem/index. php/revista/article/view/4467/pdf_5642

17. Silva JP, Garanhani ML, Peres AM. Systematization of nursing care in undergraduate training: the perspective of complex thinking. Rev Latino-Am Enfermagem. 2015; 23(1):59-66.

18. Hernández DA, Illesca PM, Cabezas GM. Opinión de estudiantes de la carrera de enfermería universidad autónoma de chile, temuco, sobre las prácticas clínicas. Cienc Enferm. 2013; 19(1):13144.

19. Toader E. Clinical simulations for learning medical skills: a work-based approach to simulators. Proc Soc Behav Sci. 2015; 197:2443-8. 